\title{
UJI EFEK ANTI INFLAMASI REBUSAN DAUN JAMBLANG (Syzygium cumini) PADA MENCIT (Mus musculus)
}

\author{
Sisilia Teresia Rosmala Dewi*), Sri Wahyuni* ${ }^{*}$ \\ ${ }^{*}$ Jurusan Farmasi Poltekkes Kemenkes Makassar
}

\begin{abstract}
ABSTRAK
Jamblang merupakan tanaman yang mengandung senyawa flavonoid, senyawa flavonoid yang terkandung dalam daun jamblang sebagai senyawa yang mempunyai aktivitas sebagai anti inflamasi Penelitian ini bertujuan untuk mengetahui efek antiinflamasi yang terkandung dalam daun jamblang, Penelitiian ini dilakukan pada bulan Juli 2016 dengan jenis penelitian eksperimental laboratorik.Sampel yang digunakan adalah daun jamblang (Syzygium cumini), yang di ambil dari kotapinrang Sulawesi Selatan. Daun jamblang dibuat dengan metode rebusan, yaitu penyarian yang digunakan untuk menyari zat-zat aktiv yang larut dalam air. Mencit yang telah dipuasakan terlebih dahulu diinjeksikan dengan larutan karagenan sebagai pemicu inflamasi kemudian diberikan rebusan daun jaamblang dengan konsentrasi 40\%, 60\% dan 80\%. Berdasarkan hasil penelitian diperoleh bahwa terjadi penurunan bengkak dengan konsentrasi ekstrak 40\%, 60\% dan $80 \%$. Pada penelitian ini digunakan kontrol positif natrium diklofenak dankontrol negatif digunakan Air hangat. Pada konsentrasi rebusan daun jamblang 80\% memiliki efek anti inflamasi yang mendekati efek anti inflamasi natrium diklofenak.
\end{abstract}

\section{Kata kunci : Rebusan Daun Jamblang, Anti Inflamasi, Mencit.}

\section{PENDAHULUAN}

Inflamasi merupakan respon perlindungan normal terhadap cedera jaringan yang di sebabkan oleh trauma fisik bahan kimia berbahaya, atau agen mikrobiologi. Inflamasi adalah usaha tubuh untuk menonaktifkan atau menghancurkan organisme penginvasi, menghilangkan iritan, dan persiapan tahapan untuk perbaikan jaringan (Andriani,2015)

Jamblang (Syzigium cumini (L.) merupakan salah satu tanamanberbuah lokal Indonesia namun dilupakan oleh sebagian besar masyarakat. Kurangnya pembudidayaan tanaman Jamblang menyebabkan tanaman ini mulai langkah.Di sisi lain, jamblang memiliki banyak manfaat Hampir seluruh bagian tumbuhan tersebut telah diketahui kegunaannya secara tradisional(Lia Marliani, 2011).

Tumbuhan jamblang ini dilaporkan mengandung senyawa kimia antara lain suatu alkaloid, flavonoid, resin, tannin, dan minyak atsiri. Tumbuhan ini memiliki banyak khasiat tidak lain karena memiliki kandungan kimia yang fungsinya dapat mengobati suatu penyakit. Salah satunya adalah senyawa flavonoid.Flavonoid merupakan salah satu metabolit sekunder yang terdapat pada tumbuhan.Senyawa ini dapat digunakan sebagai anti mikroba, obat infeksi pada luka, anti jamur, anti virus, anti kanker, dan anti tumor. Selain itu flavonoid juga dapat digunakan sebagai anti bakteri, anti alergi, sitotoksik, dan anti hipertensi (Maryati Abd.Gafur,dkk 2011).

Adapun penelitian sebelumnya tentang daun jamblang yaitu mengisolasi dan mengidentifikasi senyawa flavonoid yang terkandung dalam daun jamblang. Penelitian ini diawali dengan mengekstrak serbuk daun jamblang (Syzygium cumini) dengan pelarut metanol, bahwa secara umum genus Syzygium mengandung metabolit sekunder berupa flavonoid, alkaloid, tannin, terpenoid, yang digunakan di dalam dunia pengobatan antara lain untuk antiradang, penahan rasa sakit, dan anti jamur(Maryati Abd.Gafur,dkk 2011).

Dari uraian diatas kandungan flavonoid yang berpotensi sebagai antiinflamasi dalam daun jamblang menjadi dasar untuk penelitian ini. Dengan cara yang mudah digunakan oleh masyarakat yaitu dengan cara rebusan yang tidak mengurangi kandungan dari daun jamblang itu sendiri.

\section{Rumusan Masalah}

Berdasarkan latar belakang di atas maka permasalahan yang timbul adalah 
apakah rebusan daun jamblang (Syzygium Cumini) mempunyai efek antiinflamasi pada hewan uji mencit (Mus musculus)?

\section{Tujuan Penelitian}

$$
\text { Untuk }
$$

mengetahui

efek antiinflamasi dari rebusan daun jamblang (Syzygium Cumini) pada hewan uji mencit (Mus Musculus)

\section{Manfaat Penelitian}

1. Sebagai aplikasi ilmu dan pengalaman berharga serta dapat menambah wawasan ilmiah dan pengetahuan penulis.

2. Sebagai sumber informasi dan memperkaya ilmu pengetahuan serta sebagai bahan acuan untuk peneliti selanjutnya.

\section{METODE DAN BAHAN \\ Jenis Penelitian}

Jenis penelitian yang di gunakan adalah penelitian eksperimental yang menggunakan rancangan sederhana untuk mengetahui efek antiinflamasi dari rebusan daun jamblang (Sysygium cumini).

\section{Lokasi dan Waktu Penelitian}

Penelitian ini dilaksanakan pada tanggal Juni -Juli 2016 di Laboratorium Farmakologi Poltekes Kemenkes Makassar.

\section{Sampel}

Sampel pada penelitian ini adalah mencit(Mus musculus) yang dibagi dalam 3 kelompok.

\section{Alat dan Bahan Penelitian \\ Alat-alat yang di gunakan adalah Alat ukur manual, batang pengaduk, canula, gelas kimia, handskun, jarum suntik, kompor listrik, lap halus, lap kasar, masker,spoit. Adapun bahan yang digunakan adalah ,aquadest, Daun Jamblang (Syzygium cumini), karagenan,mencit putih (Mus musculus), Natrium Diklofenak 50mg, $\mathrm{NaCMC} 1 \%$.}

\section{Prosedur Penelitian}

1. Pengambilan dan penyiapan sampel Sampel daun jamblang (Syzygium cumini)yang diambil di kota Pinrang. Sampel dipetik dari daun kelima dari pucuk dan tidak kuning/kering pada pukul 07.00-10.00 WITA.

2. Pengolahan sampel

Sampel tanaman yang masih segar yang sudah diambil khususnya pada daun jamblang (Syzygium cumini) dikumpul, dicuci dengan air mengalir hingga bersih dan dikeringkan dengan cara ditempatkan pada tempat yang tidak terkena sinar matahari langsung.

3. Pembuatan rebusan sampel

Daun jamblang (Syzygium cumini) yang sudah kering direbus dengan air sampai mendidih, kemudian disaring dan diperas, dosis perlakuan yang diberikan adalah $40 \%, 60 \%, 80 \%$. Dosis rebusan $40 \%$ adalah : rebusan yang dibuat dari 40 gram daun jamblang (Syzygium cumini) direbus dengan 100 $\mathrm{ml}$ air. Hal yang sama juga dilakukan pada dosis rebusan $60 \%$ dan $80 \%$.

4. Pembuatan larutan pembanding

a. Natrium Diklofenak 0,050\%

Ditimbang serbuk Natrium Diklofenak $50 \mathrm{mg}$, lalu di masukan kedalam gelas kimia dan di tambahkan air $100 \mathrm{ml}$ sedikit demi sedikit sambil di aduk dengan batang pengaduk hingga homogen.

b. Pembuatan larutan NaCMC $1 \%$ b/v Natrium CMC sebanyak 1 gram dimasukkan sedikit demi sedikit ke dalam $50 \mathrm{ml}$ air suling yang telah dipanaskan, sambil diaduk dengan menggunakan batang pengaduk hingga terbentuk larutan koloidal, kemudian dicukupkan volumenya dengan air suling hingga $100 \mathrm{ml}$ dalam labu ukur.

c. Pembuatan larutan karagenan Karagenan sebanyak 0,5 gram di masukkan kedalam $50 \mathrm{ml}$ air suling yang telah dipanaskan, sambil diaduk dengan menggunakan batang pengaduk hingga homogen.

5. Penyediaan hewan uji

Hewan uji yang digunakan adalah mencit(Mus musculus) yang berbadan sehat dengan bobot badan 2030 gr yang di peroleh dari pasar burung dan telah di adaptasikan dengan lingkungan di sekitarnya.

6. Perlakuan terhadap hewan uji Mencit yang digunakan sebanyak 15 ekor yang di bagi dalam 3 
kelompok dan telah di puasakan selama

dilihat pada tabel berikut :

4 jam untuk perlakuan hewan uji dapat

Tabel 1. Perlakuan hewan uji

\begin{tabular}{cl} 
Kelompok & \multicolumn{1}{c}{ PERLAKUAN } \\
\hline I & Dengan memberi karegenin agar mencit menjadi nyeri/sakit \\
II & Diberikan air hangat sebagai kontrol negatif (-) \\
III & Diberikan Natrium Diklofenak 50mg sebagai kontrol positif (+) \\
IV & Perlakuan rebusan Daun Jamblang (Syzygium cumini) dengan \\
& konsentrasi 40\%, 60\%, 80\%. Dosis 10\% adalah : rebusan yang dibuat \\
& dari 40 gram daun jamblang (Syzygium cumini) direbus dengan 100 ml \\
& air. Selanjutnya dilakukan hal yang sama pada dosis rebusan $60 \%$ dan \\
& $80 \%$.
\end{tabular}

7. Pengamatan dan pengumpulan data Pengambilan data di lakukan setiap 1 jam selama 6 jam. Kaki mencit yang telah di suntikan karegenan dapat di amati udema yang terjadi.Kemudian hasilnya dicatat dalam bentuk tabel dan dianalisis secara statistik dengan metode rancangan acak lengkap untuk melihat efek rebusan daun jamblang (Syzygium cumini) yang diberikan bersama Natrium Diklofenak terhadap nyeri atau sebagai antiinflamasi.

\section{HASIL DAN PEMBAHASAN Hasil penelitian}

Penelitian ini merupakan penelitian ekperimental yang telah dilakukan di laboratorium Farmakologi Poltekkes Kemenkes Makassar untuk mengetahui efek antiinflamasi dari rebusan Daun Jamblang (Syzygium cumini)adapun populasi dalam penelitian ini adalah pohon jamblang (Syzygium cumini) yang ada di kota pinrang dan sampel yang digunakan adalah daun jamblang (Syzygium cumini)

Tabel 2 Pengamatan

\begin{tabular}{|c|c|c|c|c|c|c|c|c|c|}
\hline \multirow[b]{2}{*}{ KELOMPOK } & \multirow[b]{2}{*}{ REPLIKASI } & \multicolumn{6}{|c|}{ SETIAP 1 JAM SELAMA 6 JAM } & \multirow[t]{2}{*}{ JML } & \multirow[t]{2}{*}{$\begin{array}{l}\text { RATA- } \\
\text { RATA }\end{array}$} \\
\hline & & 1 & 2 & 3 & 4 & 5 & 6 & & \\
\hline \multirow[t]{3}{*}{ Kontrol + } & 1 & 2,6 & 2,4 & 2,3 & 2 & 1,8 & 1,7 & 12,8 & 2,1 \\
\hline & 2 & 2,8 & 2,4 & 2,2 & 2,1 & 2 & 2 & 13,5 & 2,2 \\
\hline & 3 & 2,0 & 1,6 & 1,4 & 1,2 & 1,1 & 1,1 & 8,4 & 1,4 \\
\hline \multicolumn{2}{|c|}{ Rata-rata } & 2,4 & 2,1 & 1,9 & 1,7 & 1,6 & 1,6 & 11,3 & 1,8 \\
\hline \multirow[t]{3}{*}{ Kontrol - } & 1 & 2 & 2 & 2 & 2 & 2 & 2 & 12 & 2 \\
\hline & 2 & 2,1 & 2,1 & 2,1 & 2,1 & 2,1 & 2,1 & 12,6 & 2,1 \\
\hline & 3 & 2,2 & 2,2 & 2,2 & 2,2 & 2,1 & 2,2 & 13,2 & 2,2 \\
\hline \multicolumn{2}{|c|}{ Rata-rata } & 2 & 2 & 2 & 2 & 2 & 2 & 12,6 & 2,1 \\
\hline \multirow[t]{3}{*}{ Rebusan $40 \%$} & 1 & 2,8 & 2,8 & 2,6 & 2,4 & 2,1 & 2,4 & 15,1 & 2,5 \\
\hline & 2 & 2,6 & 2,6 & 2,6 & 2,2 & 2,1 & 2,2 & 14,3 & 2,3 \\
\hline & 3 & 2,5 & 2,5 & 2,5 & 2,3 & 2,1 & 2,1 & 14 & 2,3 \\
\hline \multicolumn{2}{|c|}{ Rata-rata } & 2,6 & 2,6 & 2,5 & 2,3 & 2,1 & 2,2 & 14,3 & 2,3 \\
\hline \multirow[t]{3}{*}{ Rebusan $60 \%$} & 1 & 2,6 & 2,5 & 2,5 & 2,5 & 2,3 & 2,2 & 14,6 & 2,4 \\
\hline & 2 & 2,8 & 2,7 & 2,7 & 2,6 & 2,4 & 2,1 & 15,3 & 2,5 \\
\hline & 3 & 2,4 & 2,3 & 2,1 & 2,1 & 2 & 2 & 12,9 & 2,1 \\
\hline \multicolumn{2}{|c|}{ Rata-rata } & 2,6 & 2,5 & 2,4 & 2,4 & 2,2 & 2,1 & 14,1 & 2,3 \\
\hline
\end{tabular}




\begin{tabular}{rccccccccc} 
Rebusan $80 \%$ & 1 & 2,9 & 2,7 & 2,5 & 2,1 & 2 & 1,6 & 13,8 & 2,3 \\
& 2 & 2,7 & 2,4 & 2,0 & 1,9 & 1,5 & 1,1 & 11,6 & 1,9 \\
& 3 & 2,5 & 2,4 & 2,1 & 1,8 & 1,6 & 1,5 & 11,9 & 1,9 \\
\hline Rata-rata & & 2,7 & 2,5 & 2,2 & 1,9 & 1,7 & 1,4 & 12,4 & 2,0 \\
\hline
\end{tabular}

Tabel 3 Frekuensi Rata-rata

\begin{tabular}{cccccc}
\hline \multirow{2}{*}{ PERLAKUAN } & \multicolumn{3}{c}{ REPLIKASI } & TOTAL & RATA-RATA \\
\cline { 2 - 4 } & 1 & 2 & 3 & & 2,1 \\
\hline Air Hangat & 2 & 2,1 & 2,2 & 6,3 & 1,8 \\
Natrium diklofenak & 2,1 & 2,2 & 1,4 & 5,7 & 2,3 \\
Rebusan 40\% & 2,5 & 2,3 & 2,3 & 7,1 & 2,3 \\
Rebusan 60\% & 2,4 & 2,5 & 2,1 & 7 & 2,0 \\
Rebusan 80\% & 2,3 & 1,9 & 1,9 & 6,1 & 10,6 \\
\hline$\Sigma$ & 11,3 & 11 & 9,9 & 32,2 & \\
\hline
\end{tabular}

Tabel 4 Hasil Analisis dengan Menggunakan Uji Bonferroni

$\begin{array}{lccccc}\text { Perlakuan } & \text { Kons.40\% } & \text { Kons.60\% } & \text { Kons.80\% } & \text { Kontrol + } & \text { Kontrol - } \\ \text { Kons. } 40 \% & - & - & 0,006^{*} & 0,034^{*} & - \\ \text { Kons. 60\% } & - & - & 0,005^{*} & 0,034^{*} & - \\ \text { Kons. } 80 \% & 0,006^{*} & 0,005^{*} & - & - & 0,006 \\ \text { Kontrol + } & 0,034^{*} & 0,034^{*} & 0,038^{*} & - & - \\ \text { Kontrol - } & - & - & 0,006^{*} & - & -\end{array}$

\section{Pembahasan}

Udem adalah salah satu gejala terjadinya inflamasi. Mekanisme terjadinya inflamasi adalah bila membran sel mengalami kerusakan baik rangsangan kimiawi, fisik, atau mekanis maka enzim fosfolipase diaktifkan untuk mengubah fosfolipida yang terdapat didalamnya menjadi asam arakidonat kemudian untuk sebagian diubah oleh enzim siklooksigenase (COX 1) menjadi asam endoperokida dan seterusnya menjadi prostaglandin. Bagian lain dari asam arakhidonat diubah oleh enzim lipooksigenase menjadi leukotrin. Baik prostaglandin maupun leukotrin bertanggung jawab bagi sebagian besar dari inflamasi.

Uji efek antiinflamasi rebusan daun jamblang(Syzygium cumini). Yang telah dilakukan menggunakan metode pemberian udem buatan yang dibuat dengan menyuntikan larutan karagenan kedalam kaki mencit secara intraplantar kemudian diberikan rebusan daun jamblang secara peroral dalam 3 konsentrasi, parameter yang diamati adalah volume udem kaki mencit pemberian larutan karagenan akan memacu prostaglandin sehingga menyebabkan inflamasi, dimana ditandai dengan adanya pembengkakan pada kaki mencit.

Berdasarkan hasil penelitian yang telah dilakukan bahwa pemberian rebusan daun jamblang dengan konsentrasi40\%, $60 \%$, dan $80 \%$. Terjadi penurunan udem sama halnya dengan pemberian larutan natrium diklofenak sebagai obat antiinflamasi. Pada kontrol positiv digunakan Natrium diklofenak dimana natrium diklofenak salah satu obat antiinflamasi non-steroid (OAINS) yang 
digunakan untuk meredakan rasa sakit tingkat ringan hingga menengah dan inflamasi. Obat ini juga lebih cepat diserap oleh tubuh sehingga lebih sering digunakan untuk meredakan rasa sakit dan memiliki aktivitas dengan jalan menghambat enzim siklooksigenase sehingga pembentukan prostaglandin terhambat maka inflamasi tidak terjadi.

Sedangkan pada kontorol negativ digunakan air hangat (aquadest) dan tidak memberikan efek penurunan udem.Dari kelompok kontrol negatif dapat dihasilkan suatu baseline sehingga perubahan pada variabel tergantung dapat terlihat.

Pada perlakuan dengan konsetrasi $40 \%$ sedikit memberikan efek antiinflamasi dilihat pada penurunan udem setiap 1 jam selama 6 jam penurunan udem speifik lambat, penurunan udem dapat dilihat pada pengamatan ke-3, sedangankan pada perlakuan dengan konsetrasi $60 \%$ sedikit lebih cepat memberikan efek dibandingkan konsterasi $40 \%$ dilihat pada pengamatan udem spesifik turun pada pengamatan pertama namun udem turun sedikit, sedangkan pada perlakuan $80 \%$ memiliki efek antiinflamasi mendekati Natrium diklofenak dilihat pada pengamatan udem turun setiap 1 jam dengan tingkat penurunan udem cepat.

Adanya penurunan volume udem yang berarti berefek antiinflamasi pada pemberian rebusan daun jamblang karena pada daun jamblang mengandung senyawa flavonoid yang berfungsi sebagai antiinflamasi.

Untuk mengetahui ada tidaknya pengaruh perbedaan konsentrasi rebusan daun jamblang $40 \%, 60 \%$ dan $80 \%$ terhadap efek antiinflamasi pada jam ke 1 , jam ke 2 , jam ke 3, jam ke 4, jam ke 5 dan jam ke 6 maka digunakan uji statistic parametric One Way Anova, tetapi sebelum dilakukan analisa data dengan uji One Way ANOVA, maka data terlebih dahulu harus dilakukan uji normalitas dan homogenitas data, dimana salah satu asumsi dari uji One Way ANOVA bahwa data harus terdistribusi normal dan varian antar kelompok harus homogen. Dari hasil uji normalitas menggunakan uji Shapiro Wilk didapatkan nilai signifikansi untuk masing-masing data pada jam ke 1, jam ke 2, jam ke 3, jam ke 4 dan jam ke 5 yaitu $\mathrm{p}>0,05$ yang artinya data tidak terdistribusi normal. setelah itu dilakukan uji homogenitas menggunakan uji Lavene juga didapatkan nilai signifikansi untuk masingmasing data pada jam ke 1, jam ke 2, jam ke 3 , jam ke 4 dan jam ke 5 yaitu $\mathrm{p}>0,05$ yang artinya bahwa varian data tidak homogen. Data hasil penelitian tersebut menunjukkan bahwa data padajam ke 1 , jam ke 2 , jam ke 3 , jam ke 4 dan jam ke 5 tidak memenuhi syarat untuk melakukan uji One way ANOVA, sedangkan data pada jam ke 6 memenuhi syarat untuk melakukan uji One way ANOVA,

Setelah melakukan uji one way ANOVA pada menit ke 60 diperoleh nilai probabilitas $0,012>0,05$ maka hipotesis diatas ditolak yang berarti terdapat perbedaan yang bermakna atau ada pengaruh perlakuan ketiga konsentrasi rebusan daun jamblang (Syzygium cumini) terhadap efek antiinflamasi. Jika hasil uji menunjukan Ho diterima (tidak ada perbedaan), maka uji lanjut Post Hoc Test tidak dilakukan.Sebaliknya, jika hasil uji menunjukan Ho ditolak (ada perbedaan), maka uji lanjut Post Hoc Test harus dilakukan.Karena hasil uji Anova menunjukan adanya perbedaan yang bermakna, maka uji selanjutnya adalah melihat kelompok mana saja yang berbeda. Dari tabel Uji Bonferroni memperlihatkan bahwa setiap kelompok perlakuan menunjukan adanya perbedaan rata-rata pada efek antiinflamasi yang ditandai dengan tanda bintang "*", yaitu pada uji post hoc dengan menggunakan Uji Bonferroni, perbedaan antar konsentrasi dinyatakan bermakna apabila didapatkan nilai $\mathrm{p}<0.05$. Berdasarkan tabel diatas diketahui bahwa terdapat perbedaan bermakna antara konsentrasi $40 \%$ dengan kontrol positiv dan konsentrasi $80 \%$. Sementara itu, pada konsentrasi $60 \%$ juga memiliki perbedaan yang bermakna dengankontrol positiv dan konsentrasi $80 \%$. Demikian halnya dengan konsentrasi $80 \%$ memiliki perbedaan yang bermakna dengan kontrol negatif , konsentrasi $40 \%$ dan konsentrasi $60 \%$.

\section{PENUTUP}

Kesimpulan

Dari penelitian yang telah dilakukan dapat disimpulkan bahwa pemberian rebusan daun jamblang (Syzygium cumini)dengan konsentrasi $80 \%$ 
Dapat memberikan efek antiinflamsi dengan penurunan udem pada hewan uji yang mendekati efek dari natrium diklofenak sebagai obat antiinflmasi. .

\section{Saran}

1. Perlu dilakukan penelitian lebih lanjut tentang efek antiinflamasi rebusaan daun jamblang (Syzygium cumini) dengan menggunakan metode pengujian yang berbeda.

2. Perlu dilakukan penelitian uji identifikasi senyawa dalam daun jamblang (Syzygium cumini)

\section{DAFTAR PUSTAKA}

Andriani. 2015. Uji Efek Antiinflamasi kulit batang jambu mente, Edisi 1 Sekolah Tinggi Kesehatan, Makassar Hal 11-15

Endro, Nugroho, Agung., 2012, Farmakologi Obat-Obat Penting dalam Pembelajaran Ilmu Farmasi dan Dunia Kesehatan, Pustaka Pelajar, Yogyakarta

Gafur, Maryati, dkk., 2011, Isolasi dan Identifikasi Senyawa Flavonoid dari Daun Jamblang (Syzygium cumini), Universitas Gorontalo.

Harvey, Richard., 2013, Farmakologi Ulasan Bergambar Edisi Empat, Penerbit Buku Kedokteran EGC, Jakarta

Lia Marliani, dkk 2011. Vol. 1. No.2 Hal 4347. Jurnal Farmasi Galenika.Sekolah Tinggi Farmasi, Bandung

Saryono, dkk2013,Metodeologi Penelitian Kualitatif dan Kuantitatif, Edisi 1Penerbit Nuha Medika , Yogyakarta, Hal. 143-145

Siswoyo, Rini., 2013, Tumpas Penyakit dengan Buah dan Sayuran Warna Ungu, Penerbit Sakti, Yogyakarta.

Wheindrata, 2012.,Rahasia Satwa Berkhasiat Obat, Rapha Publishing, Yogyakarta.

Winkanda., 2015, Kitab Herbal Nusantara, Kata Hati, Yogyakarta 
Media Farmasi Vol. XIV. No. 1. April 2018 